\title{
Lusioersily
}

\section{Financial analysis of an installed small scale seasonal thermal energy store}

Colclough, S., \& Griffiths, P. (2016). Financial analysis of an installed small scale seasonal thermal energy store. Renewable Energy, 86, 422-428. https://doi.org/10.1016/j.renene.2015.08.032

Link to publication record in Ulster University Research Portal

\section{Published in:}

Renewable Energy

Publication Status:

Published (in print/issue): 01/02/2016

DOI:

10.1016/j.renene.2015.08.032

\section{Document Version}

Author Accepted version

\section{General rights}

Copyright for the publications made accessible via Ulster University's Research Portal is retained by the author(s) and / or other copyright owners and it is a condition of accessing these publications that users recognise and abide by the legal requirements associated with these rights.

\section{Take down policy}

The Research Portal is Ulster University's institutional repository that provides access to Ulster's research outputs. Every effort has been made to ensure that content in the Research Portal does not infringe any person's rights, or applicable UK laws. If you discover content in the Research Portal that you believe breaches copyright or violates any law, please contact pure-support@ulster.ac.uk. 


\title{
Financial analysis of an installed Small Scale Seasonal Thermal Energy
}

\section{Store}

\author{
Shane Colclough *, Philip Griffiths \\ Centre for Sustainable Technologies, University of Ulster, Newtownabbey, BT37 0QB, Northern Ireland, \\ UK, Phone +44-28-90366907, Fax +442890368239 \\ * Corresponding author: Shane Colclough s.colclough@ulster.ac.uk,
}

\begin{abstract}
The financial viability of an installed solar heating system incorporating a Seasonal Thermal Energy Store (STES) for a house constructed to the low-energy Passivhaus standard is analysed. Details are provided of system costs and the recorded performance for the installation which is located in Galway, Ireland, a location which experiences a Temperate Maritime Climate. Using these figures, a financial Life Cycle Analysis has been undertaken to determine the cost effectiveness of the system in providing space heating and domestic hot water.

As part of the life cycle cost analysis the effect of the treatment of the terminal value of the STES was considered. The analysis shows that irrespective of the terminal value attached to the STES, the use of solar thermal energy in combination with an STES offered a more favourable business case than the use of electricity for DHW and space heating over the 40 year time period considered. This shows that a direct space heating and DHW system incorporating STES can be economically viable in a Temperate Maritime Climate in the long
\end{abstract} term.

Key words: Passivhaus, Seasonal Thermal Energy Storage, STES, Financial Analysis, combi systems, Low Energy House

\section{Highlights}

- A Passivhaus with a STES based Solar Thermal heating system is analysed

- Recorded performance figures and system costs are presented

- The payback periods for the STES based heating system are presented

- The STES system is financially attractive within the 40 year planning horizon

- System optimisation would further increase the attractiveness of the system

\section{Introduction.}

Regulations, such as those mandated as a result of the EU's Energy Performance of Buildings Directive [1], are seeking to significantly reduce the space heating demand of dwellings while increasing the use of renewables to meet the residual energy demand. A study of the performance of houses complying with the (now 20 year old) low energy Passivhaus standard [2,3] provides an insight into the future performance of the now mandated low-energy buildings. A number of studies (for example [4], [5], [6], [7]) have documented the performance of the Passivhaus dwelling in various climates. In particular, in the EU funded CEPHEUS (CostEffective Passive Houses as EUropean Standard) project, the operation of 221 low energy housing units complying with the Passivhaus standard in five European countries was evaluated [4]. It demonstrated a space heating energy reduction of over $75 \%$ compared with building regulations pertaining at the time and over $90 \%$ when compared with the typical building stock [8]. When there is a low space heating demand in the dwelling, the opportunity for meeting a significant portion of thermal energy demand (space heating and hot water) with renewable resources such as solar become feasible.

The usefulness of solar energy for heating buildings is a function of the ratio of incidental insolation to heat loss [10]. The profile of the space heating demand is seen to be important. Thus, for example, buildings in cities with excellent solar resources and short heating seasons (e.g. Valetta, Malta) benefit less from solar space 
heating than those in cities such as Dublin, Ireland which have less available solar energy, but experience a longer heating season, with a relatively mild winter, leading to low peak space heating demands [11].

The falling prices of solar collectors, and the relatively high set cost of installation, allows for excess solar collectors to be added at minimal extra cost thereby significantly increasing the Solar Fraction (SF) of DHW and space heating of a low-energy house, reducing significantly the carbon derived energy demand. Surplus heat generated in summer can be fed to a Seasonal Thermal Energy Store (STES) allowing surplus summer heat to be used in the winter [12].

While much has been written on large communal STES (for example [13], [14], [15]) consideration also needs to be given to STES for single dwellings such as that in this study. There are a number of countries in which the largest proportion of newly constructed houses are detached dwellings such as in Ireland where 54.2\% (2010), 62.3\% (2011), 61\% (2012), 57\% (2013) of new build are detached [16], as has been referred to by other studies e.g. [17].

A number of papers have focused on the analysis of STES systems in combination with low Energy houses through the use of dynamic building simulation software such as TRNSYS (eg [18], [19], [20]), a number of which also undertook financial analysis. However, few examples exist of a financial analysis based on recorded costs and monitored performance of an installation.

This paper analyses the financial viability of the application of a space heating and Domestic Hot Water (DHW) solar thermal installation utilising Seasonal Thermal Energy Storage (STES), to a dwelling complying with the Passivhaus standard in a temperate maritime climate (TMC) based on recorded data, in a location with a four year average Heating Degree Days of 2063 [22].

\section{Overview of Installation}

A Passive House of $215 \mathrm{~m}^{2}$ constructed in Galway, Ireland in 2006, has a very low predicted space heating demand of $1827 \mathrm{kWh}$, as determined by the PHPP, when it is used as a residence for a family of four. The house is currently used primarily as an office and show house, but also has periods when it is lived in.

In June 2009, an underground aqueous Seasonal Thermal Energy Store was installed and used to supplement the dwelling's installed electric space heating. Previous publications have provided details for the relative climate, the passive houses construction details, the solar installation, it's operational performance, a Net Energy Analysis and the optimisation of the solar thermal installation applied to the passive house through numerical modeling [22], [23], [24], [25], [26], [27].

An Evacuated Tube Solar collector array, of $10.6 \mathrm{~m}^{2}$ aperture, collects diurnal heat and stores it indirectly in a 300 litre DHW (DHW) cylinder ("Tank 1") via a heat transfer coil. Once the temperature of the DHW tank reaches a temperature above which legionella cannot survive $\left(65^{\circ} \mathrm{C}\right)$, a three way valve originally diverted the solar heated fluid via a heat exchanger coil, to a subterranean STES ("Tank 2") of capacity 22,730 litres, which is located in the garden. The water in Tank 2 is not circulated and is used purely as an indirect sensible heat store.

In November 2010, this system was modified such that once the DHW temperature exceeds $65^{\circ} \mathrm{C}$, the solar fluid is fed to the space heating system ("Direct Space Heating"), until the house temperature reaches $22^{\circ} \mathrm{C}$, whereupon the solar fluid is fed to the STES. The energy stored in Tank 2 is used in the underfloor heating, which is in the wetrooms, and whole house air duct space heating system via a heat exchanger coil. It also indirectly heats the DHW supply via the preheat coil in tank 2.

Overall the arrangement ensures, a) the SF for DHW is high, b) heat surplus to DHW need is used for direct space heating, c) any surplus heat is stored for winter use rather than rejected (as would be the case in holiday mode), and d) the space heating SF in winter is increased.

The STES storage cycle commences in February with the lowest tank temperature and finishes the following February once the captured summer solar energy has been utilised during the winter period. Due to the design employed, thermal stratification does not occur to any great extent in Tank 2 , with the recorded temperature difference between the top and bottom of the tank rarely exceeding $2^{\circ} \mathrm{C}$. 


\section{$3 \quad$ System Performance \& Costs}

\subsection{Space Heating}

The performance of the system has been monitored since June 2009. System optimisation was undertaken in the first heating season, and the results are thus atypical. In addition, the house was unoccupied or infrequently used for the period June 2011 to October 2013. The overall period for which results are presented here is from March 2010 to May 2011, which represents the most typical system usage pattern.

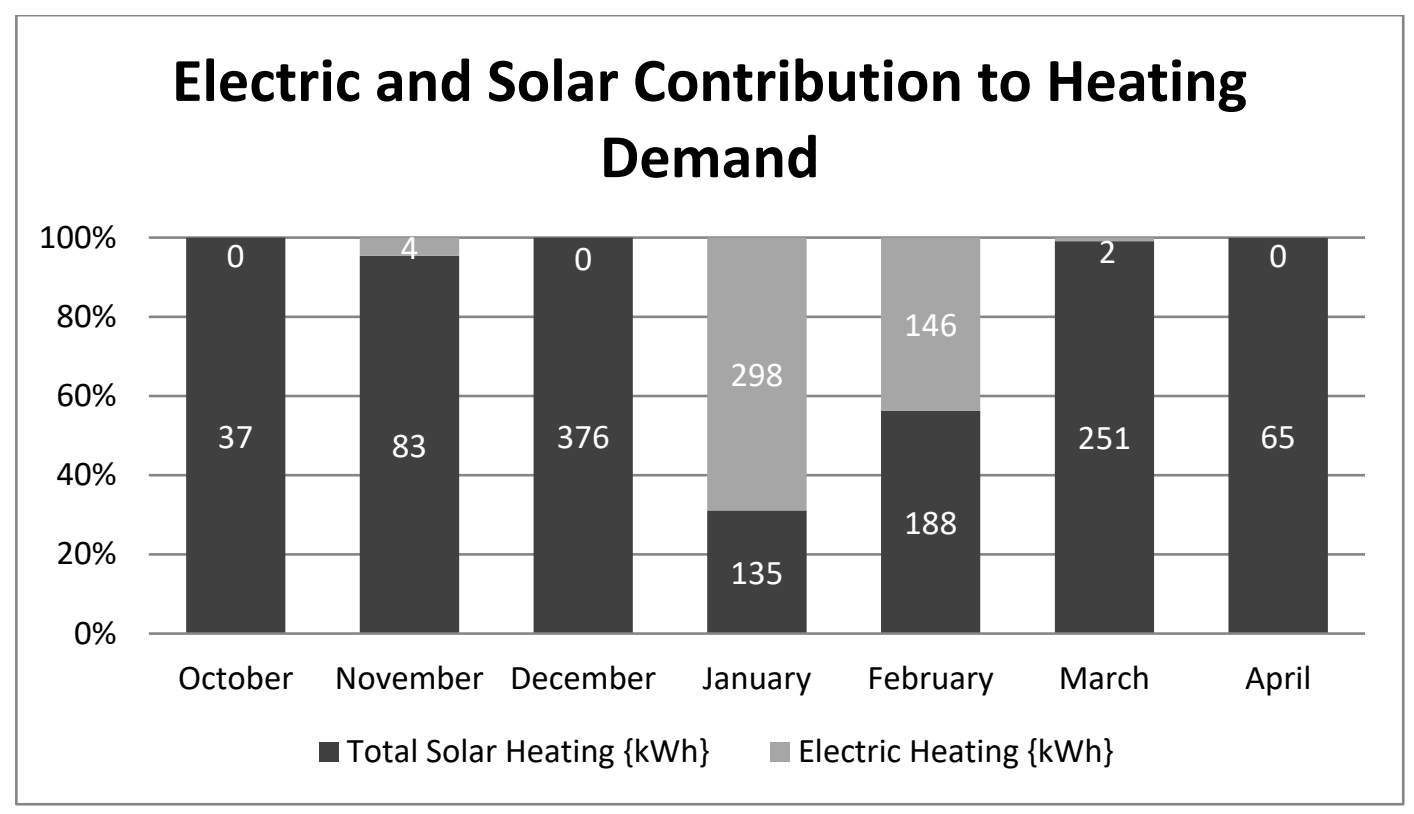

Fig 1 Space Heating Demand for Heating Season Analysed showing Solar Fraction

Fig 1 shows that the space SF approached $100 \%$ for all months apart from January (31\%) and February $(56 \%)$. Thus the space heating needs were met either by direct solar space heating or via stored solar heat for all but two months of the year.

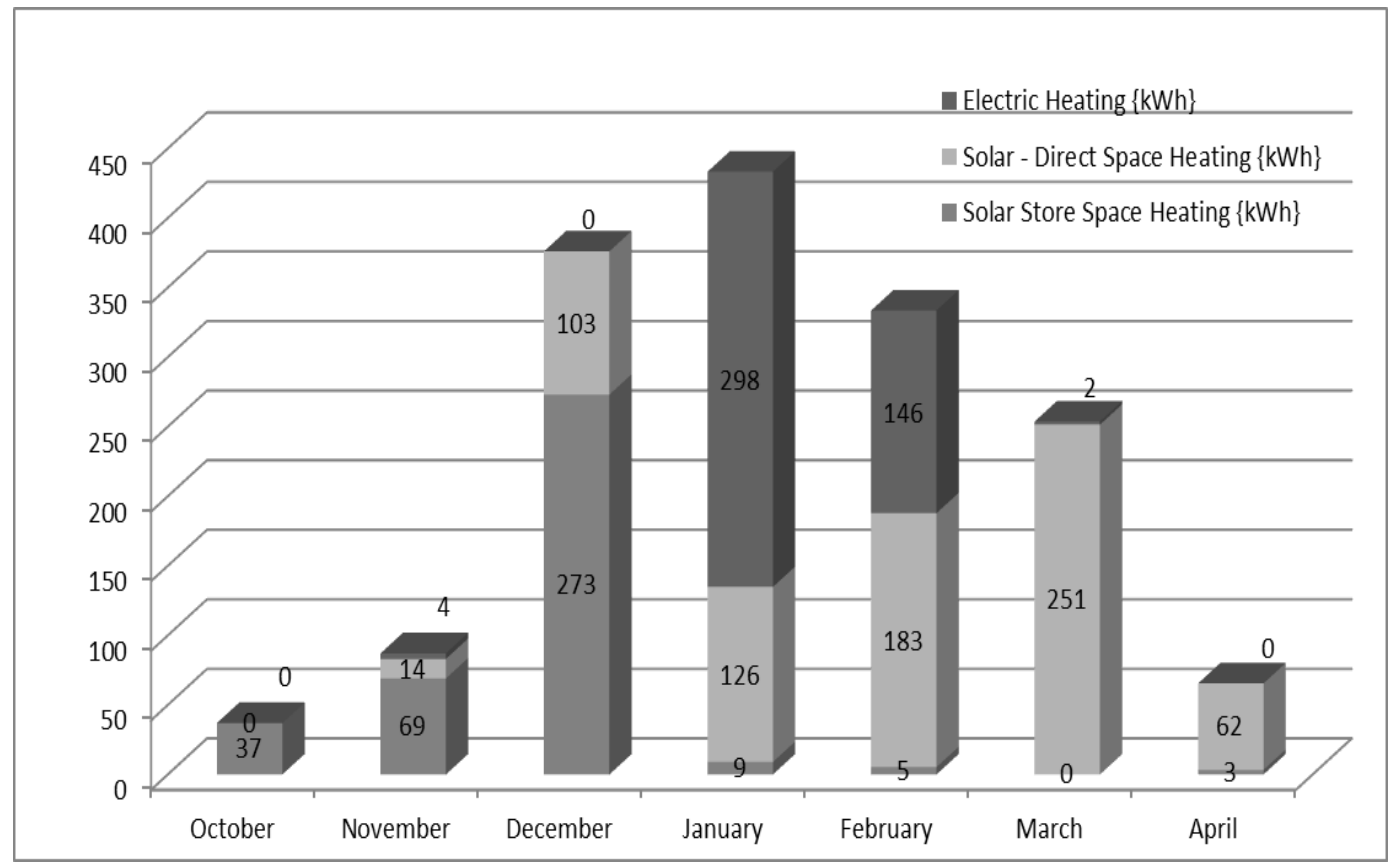

Fig 2 Electric, Direct Solar, and Stored Solar Space Heating, Oct to Apr 
Of the total space heating demand of $1592 \mathrm{kWh}$ between June 2010 and May 2011, only $450 \mathrm{kWh}$ was borne by the electric heating system. The SF over the space heating season was $72 \%$, with $739 \mathrm{kWh}(46 \%)$ of the total space heating demand being met by direct solar space heating via the heat exchanger coil in the HRV System and the wet underfloor heating system, with the remaining $406 \mathrm{kWh}(26 \%)$ provided by the seasonally stored heat. It is noted that the Passive House Planning Package (PHPP) forecast an annual space heating demand of $1832 \mathrm{kWh}, 236 \mathrm{kWh}$ above the recorded space heating demand over that period. The PHPP, while not a dynamic building simulation tool, has received extensive validation and the PHPP model is accepted as an accurate predictor of space heating demand. The lower than predicted space heating demand may be due to the fact that internal temperatures of less than $15^{\circ} \mathrm{C}$ were experienced for 15 days due to the house being unoccupied for part of December and January. Temperatures across Ireland dropped to record lows in December 2010. Apart from December and January the internal temperatures always exceeded $17^{\circ} \mathrm{C}$, even during periods when the house was unoccupied.

Figure 2 shows the breakdown on a per month basis between electric heating, direct solar space heating and stored solar space heating for the heating season 2010 to 2011. It can be seen that the STES made a significant contribution in October, November and December, but was depleted by January 2011. In 26 November 2010 the solar heat system was adapted to provide a connection to the existing HRV system in the house as described earlier. This enabled solar heat collected by the $10.6 \mathrm{~m}^{2}$ solar array to be used to directly heat the dwelling rather than via the intermediary of the STES, the effects of which are clearly visible in figure 2 .

\subsection{DHW Consumption}

The domestic hot water consumption recorded at the site was low at $852 \mathrm{kWh}$. This reflects the use of the building as an office/showhouse during the period analysed rather than a domestic dwelling and also a low occupancy level. The total solar contribution to DHW was $792 \mathrm{kWh}$ for the period (SF of In the following analysis, the recorded domestic hot water consumption has been used.

\subsection{System Costs}

Table 1 provides an itemised breakdown of all the generic costs associated with the project, as recorded by the builder. It excludes the costs of the monitoring equipment, and costs associated with the site specific tasks such as felling of trees, the installation of a greenhouse over the STES etc. It also assumes that a heat transport mechanism is installed, this being a reasonable assumption for a 'passivhaus' given that a HRV System is mandatory.

Table 2 gives a breakdown of the total generic DHW and space heating system costs for the installation in Galway. The cost of the solar DHW installation $\left(10.6 \mathrm{~m}^{2}\right.$ solar array coupled with a $300 \mathrm{~L}$ tank) is considered the base system. The cost of the heat exchanger coil plus a three-way valve (plus labour costs) are itemised as the direct solar space heating system. The extra cost of the STES is detailed.

In compiling Tables 1 and 2, the following is noted:

- $15 \%$ of total manpower costs is attributable to the DHW installation

- $5 \%$ of total manpower costs is attributable to the HRV System

- $80 \%$ of total manpower costs is attributable to the STES installation and site works

- Site specific costs are excluded, e.g. greenhouse over seasonal store, tree felling and Chipping of wood

- Installation costs of heating equipment in house not included

\section{Costs include VAT}

The costs were validated against the costs and sizing of European installed combisystems as undertaken by the International Energy Agency Solar Heating and Cooling programme (IEA-SHC) Task 32 study [28] and found to be within the normal range of combisystems costs. 


\begin{tabular}{|c|c|c|c|}
\hline \multicolumn{2}{|c|}{ Costs for Typical solar seasonal store project } & \multirow[b]{2}{*}{ Suppl } & \multirow[b]{2}{*}{ Price $\{€\}$} \\
\hline Item & Descr. & & \\
\hline \multicolumn{2}{|l|}{ Equipment; Solar Installation } & & \\
\hline Solar Collectors & 6x Vacuum U-tube 1.8m2 & Sunking & 3,000 \\
\hline Controller & Steca TR 0603 & Säljex & 320 \\
\hline Pumpstation & Tacosol FV70 3.0 ZR (Grundfos UPS 25-60 130 3sp) & Existing & 215 \\
\hline Temperature Sensor & PT 1000 & & 78 \\
\hline Thermostatic regulating valve & Duco mixautomat & & 40 \\
\hline 3-way motorized valve & Wege-Motor-Umschaltventil & ICMA & 69 \\
\hline Expansion tank for solar & ICMA 35 lit w kit & ICMA & 53 \\
\hline \multicolumn{2}{|c|}{ Automatic aeriator valve for top position } & Existing & 3 \\
\hline Flow Meter & Steca TA VM1 & Steca & 220 \\
\hline Antifreeze concentrated & 20 lit & ICMA & 89 \\
\hline \multirow[t]{2}{*}{ Duct heater } & water to air heat exchanger & VEAB & 200 \\
\hline & & Sub total & 4,287 \\
\hline \multicolumn{4}{|l|}{ Equipment; Seasonal Store } \\
\hline Internal tank (tank 1) & Huch SSH 300 enamelled 2-coil 300lit & Existing & 1,039 \\
\hline Underground tank: (tank2) & $23 \mathrm{m3}$ & Carlow precast & 5,350 \\
\hline Excavation for tank2 & & B. Faherty & 1,404 \\
\hline Insulation: Spray $(200 \mathrm{~mm})$ & spray on soya insulation applied to wall & Abbey Ins & 1,300 \\
\hline Insulation: EPS Board & EPS $400 \mathrm{~mm}$ wall, $600 \mathrm{~mm}$ floor\&top & Quinn & 1,760 \\
\hline Pipework from tank to house & flexrohr twin ss DN20 14mm insul 2x.75mm 25m & Säljex & 829 \\
\hline \multirow[t]{2}{*}{ Tank 2 Heat Exchanger } & 22mm finned copper pipes, $22 \mathrm{~mm}$ smooth copper & Cupori & 663 \\
\hline & & Sub total & 12,345 \\
\hline \multicolumn{4}{|l|}{ Miscellaneous site costs } \\
\hline Floorheatpipes & $14 \mathrm{~mm}$ ext dia, $10 \mathrm{~mm}$ int dia sauerstoffdicht DIN 472c $3 \times 50 \mathrm{~m}$ & Existing & 150 \\
\hline Expansion tank for floorheat & ICMA 18 lit w kit & Existing & 41 \\
\hline Pump for floorheat: & Grundfos & & 150 \\
\hline mixervalve to floorheat & & & 30 \\
\hline Floor Heat distribution panel & stainless steel $4-14 \mathrm{~mm}$ & & 145 \\
\hline with thermostatic valves for pipes & & Sub total & 516 \\
\hline \multicolumn{4}{|l|}{ Labour } \\
\hline \multirow[t]{2}{*}{$\begin{array}{l}\text { Labour to install tank2 culvert, } \\
\text { pipes, install solar panels, all } \\
\text { inside and out + misc local } \\
\text { materials }\end{array}$} & & Rostaff & 11,195 \\
\hline & & Total & 28,344 \\
\hline
\end{tabular}

Table 1 Generic Project Costs for Solar Project in Galway

\begin{tabular}{|r|r|r|r|}
\hline & Solar DHW & Solar Space Htg & \multicolumn{1}{c|}{ Seasonal Store } \\
\hline & Total cost $€$ & Extra Cost $€$ & Extra Cost $€$ \\
\hline Parts & 5057.00 & 269.00 & 11822.30 \\
Labour & 1679.30 & 559.77 & 8956.27 \\
Total & 6736.30 & 828.77 & 20778.57 \\
\hline
\end{tabular}

Table 2 Estimated Costs of Typical Solar DHW, Seasonal Store and Space Heating System

\section{Results and Discussion}

\subsection{Life Cycle Cost and Savings Analysis}

A life Cycle Cost (LCC) analysis using the time value of money as outlined by Kalogirou [29] was carried out over a 40 year period. Life-cycle cost analysis is a tool to determine the most cost-effective option among different competing alternatives to do a project, when each is equally appropriate to be implemented on technical grounds. All the costs are usually discounted and totaled to a present day value known as net present 
value (NPV) using a discount factor d, which bring the individual future values of money to their present day value .

A 40 year period has been chosen for the financial analysis given the significant capital investment costs required for the seasonal thermal energy store and the long service life of the STES. The investment in a STES is not expected to pay back in a short timeframe, but rather is assumed to be part of the energy infrastructure of the dwelling in the same way as appropriate orientation and insulation.

The analysis does not take into consideration the cost of financing the investment, tax incentives or annual corporate tax treatments. Emphasis is given in the life cycle analysis to the service life of the components.

It should be noted that tax incentives, such as the accelerated capital allowances currently available for investment in renewable energies in a number of countries such as the U.K.'s Renewable Heat Incentive (RHI) [30] would significantly increase the attractiveness of the installation.

Persson and Westmark [31] noted the significant emotional, cognitive and social factors at play when consumers make investment decisions in STES systems, and have analysed the effects of behavioural economics in such systems. For the purposes of this study, behavioural economics are not analysed and the neoclassical economics approach has been adopted.

\subsection{Expected Life of the Equipment}

Given that solar thermal is a mature technology, the various components carry long warranties and it is anticipated that with minimal intervention, systems will continue to operate for 15 to 40 years [32].

In this analysis, the cost has been allocated for scheduled maintenance (mtce) of the system every six years, in line with the maintenance schedule carried out at the installation, and it is assumed that the solar thermal system will continue to operate for 20 years without further capital investment.

Unless otherwise stated, the analysis has assumed that the value of all equipment at the end of the 20 year period is zero. This leads to the "worst-case scenario" for the financial analysis, and the approach has been to adopt this conservative financial modelling throughout the remainder of the analysis.

However, while this is a reasonable assumption in the case of the DHW and space heating systems, considerable value can still be attributed to the STES at the end of the 20 year period. The question of how to value this resource can be approached in a number of ways. In this study the scenario of 40 years operation is considered. In the 40 year analysis, it is assumed that a system overhaul of the solar collector, DHW and direct space heating and seasonal energy storage heat exchanger coils will be required at a cost equivalent to the initial investment and adjusted for inflation and the discount rate. It is assumed that the STES tank and DHW tank will not require any extra investment. Research work on green valuation, as a result of the requirements for energy performance certificates, and legislation that demands a basic level of energy performance for rented accommodation, may see low and zero carbon technologies obtain a value, whereas today they are ignored.

\subsection{Capital Costs}

The capital costs in the life cycle analysis are those of the typical installation already outlined in Table 2.

In the analysis it is assumed that the capital costs of the space heating elements are negligible as an electrical space heating element is typically standard in HRV Systems. Thus they have been eliminated from both the solar and electric space heating analyses. In addition, it is assumed in the analysis that an existing HRV System is available as a heat delivery mechanism and an extra heat transport mechanism is thus not required.. As previously outlined, this is a reasonable assumption given that the house under study is constructed to the Passivhaus standard. In the house under study, a wet underfloor heating system has been used occasionally in conjunction with the HRV System. However given that it is possible to heat the house using the heat exchanger coil in the HRV System exclusively, the costs of the underfloor heating installation are ignored.

\subsection{Pump Operation and associated costs}

In analysing the costs associated with the solar heating system, the annual running costs in addition to the capital costs (which have already been considered) must be included. 
It is estimated that the underfloor/HRV System heating pump consumes $44 \mathrm{kWh}$ of electricity during the period of operation considered. This figure is used when calculating the amount of energy consumed by the pump in transferring heat from the STES.

The same pump make and model is used in the solar circuit, and it is calculated that the total consumption over a year is $42 \mathrm{kWh}$. In the analysis, this energy consumption is spread on a pro rata basis to each of the three target systems, based on the energy transferred to the target system. Based on the recorded losses associated with the STES, in the analysis it is assumed that 2.5 times as much energy is transferred to the STES, as is drawn from it.

A maintenance check is carried out and a glycol solution is added to the water in the solar circuit every six years. It is assumed that this costs $€ 150$ (at today's prices).

In order to estimate the costs involved in an overhaul of the system, a cost equivalent to the full system cost of the DHW and HRV System, including replacement of the solar panels, is allocated to year 20, and multiplied by the appropriate inflation conversion and Net Present Value (NPV) factors, resulting in a cost allocation of $€ 6,523$ in year 20 . Thereafter, the six yearly maintenance interval continues to be scheduled, with the first scheduled maintenance intervention occurring six years after system overhaul.

\subsection{Treatment of the time value of money}

A Life Cycle Cost and Savings analysis has been carried out with a number of different variables and results presented here using;

Annual Discount Rate $d=3 \%$

This is based on the required IRR (Internal Rate of Return) within the company concerned at the time of the analysis.

Annual Rate of Inflation $i=2.2 \%$,

This reflects the average of the Irish rates of inflation reported by Eurostat from 2001 to 2011 [33]

Annual Rate of Electricity Inflation $i_{e}=7.3 \%$

This reflects the 11 year average rate of electricity inflation calculated using the eurocent Unit price of Domestic Electricity in Mar 2002 at 10.71c (source ESB bills) and in March 2014 at 19.28c (source ESB [34]). This represents an increase of $8.57 \mathrm{c}$, or $80.01 \%$ in 11 years, equivalent to $7.27 \%$ on an annual basis). The rate of 19.28c excludes any Public Service Obligation (PSO) levy, (a government charge to cover the higher costs of peat and renewable energy in Ireland) as this cost is currently based on an annual charge rather than a charge per unit of electricity. 4.6 NPV for DHW

Figure 3 gives a graphical representation of the NPV data for the cost of Solar Vs Electric DHW excluding the STES. The graphical representation allows the breakeven point to be readily established.

The base case (i.e. using only electricity for DHW clearly has the lowest initial cost in year one, comprising the cost of the DHW cylinder and immersion heater. However the NPV of the base case is high at $€ 15,396$ reflecting the high annual running costs. Given the extra capital investment in year 20 (reflecting a replacement of all equipment excluding the STES), breakeven does not occur until year 39, the year after which reinvestment will be required in the solar installation. Given the low DHW consumption, the extra investment required in a large solar panel array is not economically justified. It should be noted that in order to satisfy the annual $705 \mathrm{kWh}$ DHW load alone, a $2 \mathrm{~m}^{2}$ solar array coupled with a $200 \mathrm{~L}$ DHW tank would typically be used, rather than the $10.6 \mathrm{~m}^{2} / 300 \mathrm{~L}$ arrangement considered here. 


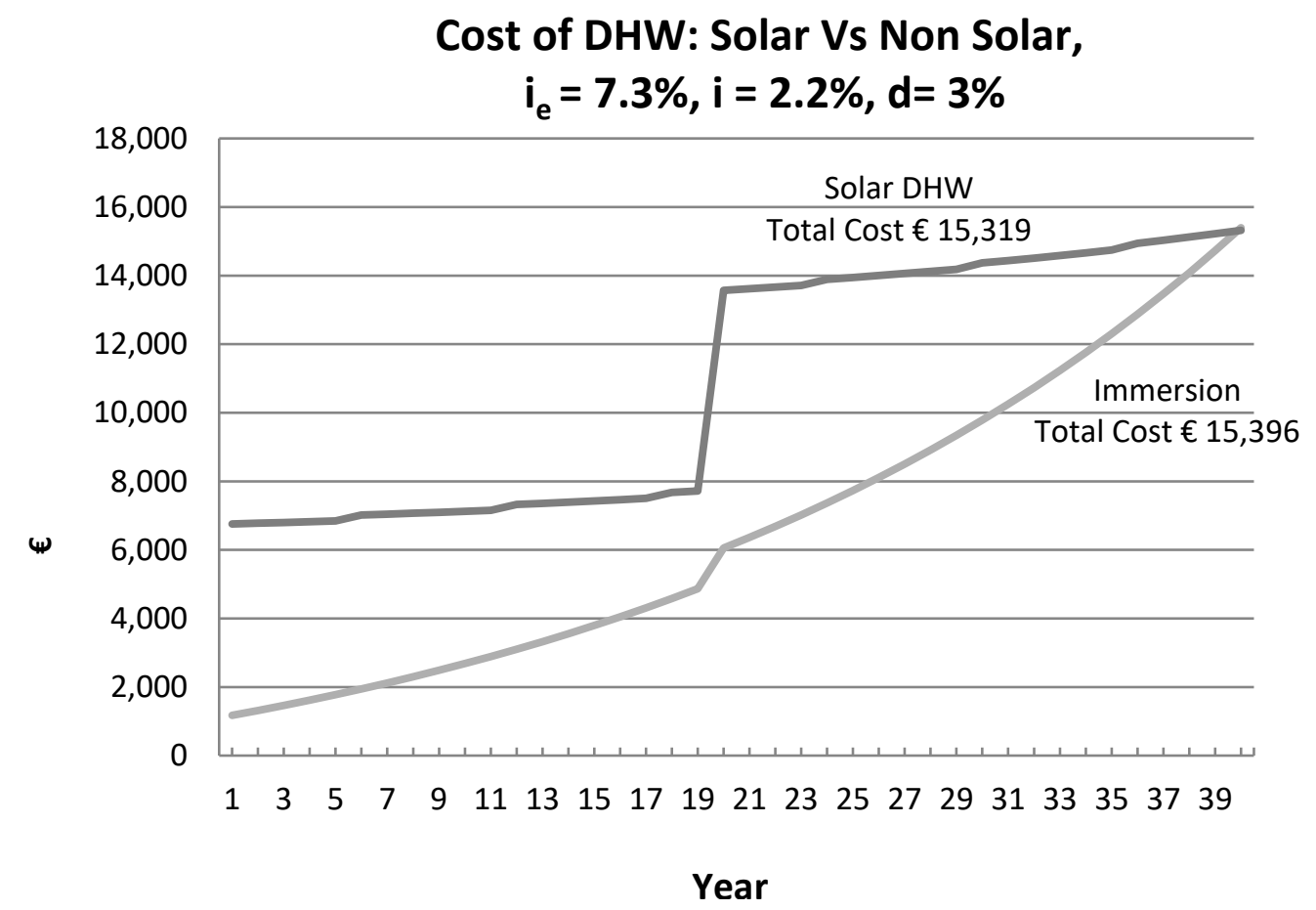

Figure 3 Solar Versus Non-Solar DHW NPV's

4.6 NPV for Space Heating

Cost of Space Htg: Solar Vs Electric,

$i_{e}=7.3 \%, i=2.2 \%, d=3 \%$

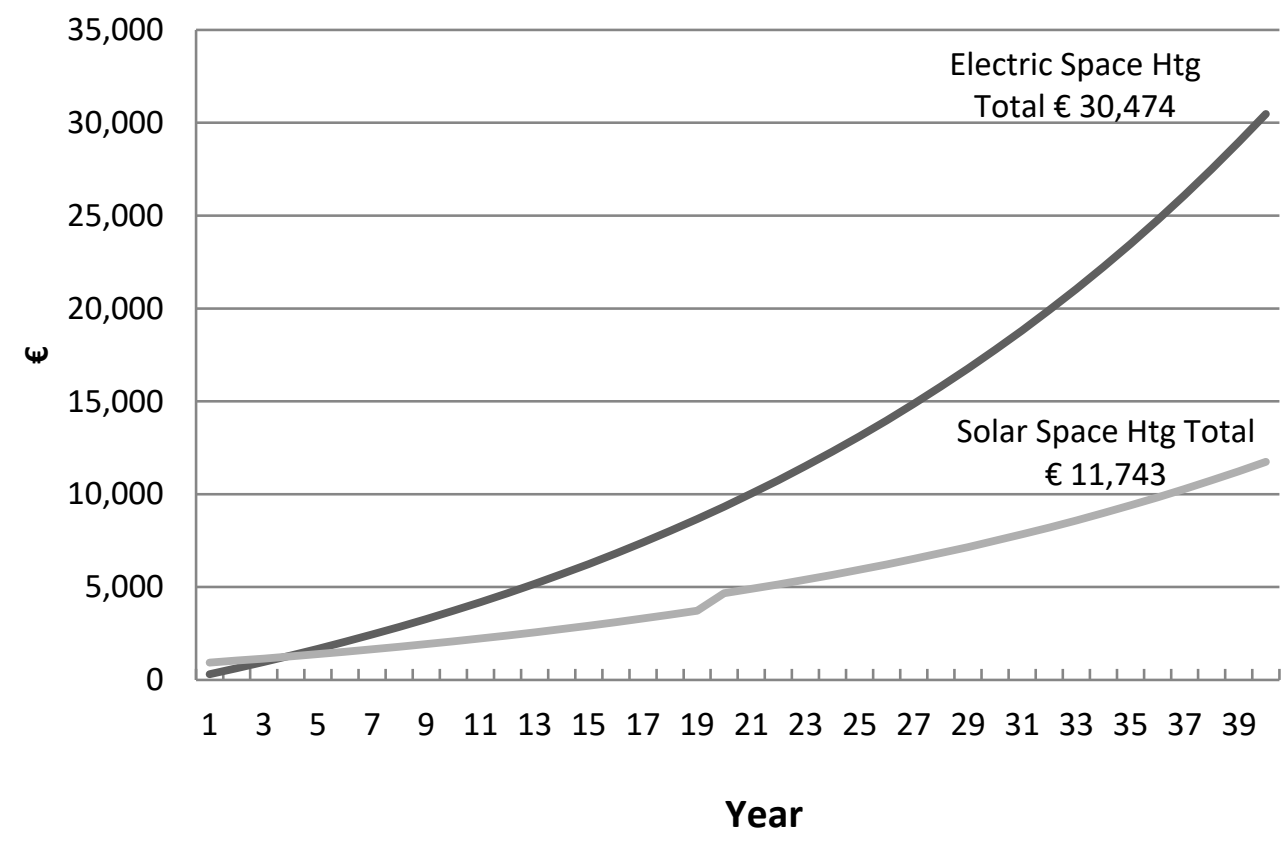

Figure 4 Solar Versus Electric Direct Space Heating NPV's 
In the case where solar energy is used for both DHW and direct space heating (without the benefit of the STES), the NPV for space heating is $€ 11,743$ compared with $€ 30,474$ if electricity is used, as can be seen in Fig 4. This reflects the relatively low capital investment required for direct solar space heating. Due to the atypically low DHW consumption, a significant surplus of solar energy is available to directly meet the $1596 \mathrm{kWh}$ space heating needs. In this case, the breakeven point occurs in year 5, after which time savings are made compared with the base case.

\subsection{NPV for DHW \& Space Heating incorporating the STES}

Finally, considering the use of solar for DHW and space heating and including the installation of the STES, the NPV of $€ 43,083$ is arrived at, as shown in Fig 5. This represents a saving on the base case of using electric space heating even without consideration of the terminal value of the STES despite the low DHW demand and low space heating demand of the low-energy house under consideration.

One of the most significant variables in the analysis of the financial performance of the complete solar heating system is that of the value of the STES at the end of the 40 year planning horizon. Thus consideration is required of the NPV of the terminal value of the STES.

The value inherent in the installed STES is difficult to estimate. Given that it has an exceptionally long predicted service life and can be used over a longer planning horizon than the 40 years considered, a terminal value of $€ 7,481$ is assigned reflecting that $50 \%$ of the initial value of the STES will remain at year 40 given its' 80 year economic life and adjusting for NPV. When the terminal value of the STES is subtracted from the NPV of the solar DHW and space heating system, a revised NPV of $€ 35,602$ is arrived at. This represents a significant saving of $€ 10,269$ on the NPV of the base case (for electrical heating) of $€ 45,871$. Consideration of the terminal value of the STES reduces the payback from 38 years to 34 years.

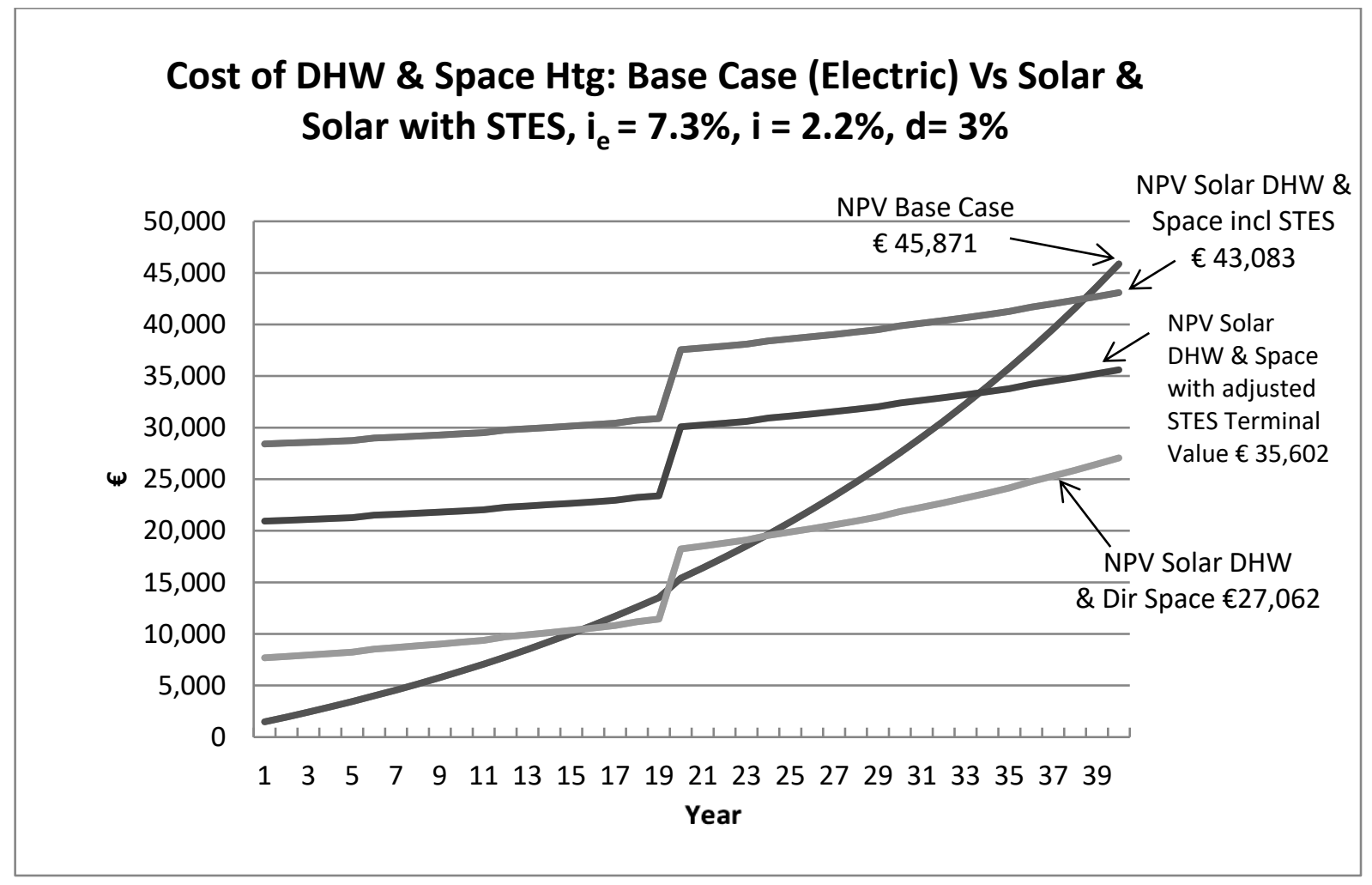

Figure 5 NPVs Incorporating Seasonal Thermal Energy Storage

Finally, figure 5 also gives the NPV of the solar DHW and direct heating system (excluding the STES) at $€ 27,062$. This clearly represents a significant saving on the NPV of the base case of electrical heating of $€ 45,871$, and represents the most attractive investment option. The payback period is 15 years, and given that an investment will be required in year 20, breakeven is again achieved in year 24 , after which significant savings accumulate. 


\subsection{Discussion}

The financial analysis undertaken using net present values demonstrated that there is a strong case for direct solar space heating compared with the use of electricity with payback for the solar space heating "upgrade" being achieved in year 5. However the solar space heating upgrade assumes that a solar DHW installation is in place, and the financial viability of the solar DHW system is poor when considered in isolation.

The reason for the poor viability of the solar DHW system is due to the exceptionally low DHW consumption profile and the very high installed costs of the $10.6 \mathrm{~m}^{2}$ solar array which far exceeds the $3 \mathrm{~m}^{2}$ which would typically be required for DHW. Thus the NPV of the combined solar DHW and direct space heating system needs to be considered. The payback of the combined system is seen to take place in year 15 as can be seen in Figure 5.

It is thus seen that while figure 3 and figure 4 provide insights into the business case for the individual elements, figure 5 provides the required holistic view for consideration of the key overall financial analysis of the installation.

Looking at figure 5, the lowest NPV is that for the solar domestic hot water and direct space heating system. However, what is not immediately evident is that the oversized solar array requires a heat dump in order to achieve the high solar fractions recorded. For the specific installation in Galway, the facility to dump surplus summer heat (thereby avoiding stagnation) has been provided by the STES, and a portion of the surplus summer heat has been reused to provide $25 \%$ of the space heating demand during the winter. The alternative to using the STES as a heat dump, is to install a system to dispel the excess heat during the summer at extra cost e.g. a radiator which is exposed to the elements. The extra cost of this system has not been considered in the analysis.

Previous publications ([23], [26]) highlight that the installation carried out by the builder was neither optimally designed nor installed. The store design eliminated stratification and the pipeline length to and from the thermal store was excessive (18m each way), both of which worked to reduce the efficiency of the STES. In the case of the transfer of heat from the STES to the space heating system, the resultant heat transfer loss of $17.6 \%$ has been recorded [23]. In addition, using a Trnsys model of the installation, a further $30 \%$ reduction in the fossil fuel derived energy demand could have been achieved by increasing the solar array from $10.6 \mathrm{~m}^{2}$ to 20 $\mathrm{m}^{2}$ [26]. The extra costs associated with doubling the solar array is approximately $€ 3,000$ (see table 1). Thus by improved design, the system performance could potentially be increased by approximately $50 \%$ for marginal extra financial outlay. Finally, the space heating system utilises direct space heating, (i.e. without the benefit of a diurnal store). It is anticipated that further increases in efficiency could be obtained simply by using a combined DHW and space heating buffer tank. Further work is required to determine the impact of a diurnal store on the performance and financial viability of the installation.

\section{Conclusion}

The analysis shows that, for the specific house under study, the use of a Solar Energy system incorporating an STES for DHW and Space Heating shows financial savings compared with the use of electric heating given the timeframes consistent with the service life of the STES.

The analysis has been carried out for a specific installation in Galway, Ireland for which the system costs were detailed and validated by benchmarking against the costs of similar combisystems as reported by the IEA. In addition, the analysis is based on recorded performance figures from the installed system. Further, the financial variables were chosen for the specific company, the country, and the time of the study.

There are both advantages and disadvantages associated with using actual system costs and recorded performance figures for the installation. The approach of grounding the analysis in a real installation provides the benefit of providing real figures in the analysis, rather than figures based on theoretical system modelling. However, opportunities exist to significantly improve the installation, which has resulted in higher costs for the STES based system than are achievable for an optimised installation.

It is clear that had optimal design been carried out prior to commencing the installation, increased system performance of approximately $50 \%$ could have been achieved for minimal extra financial outlay, significantly improving the business case for the STES based solar thermal system studied. Further analysis is required to determine the impact on the financial viability of improved design on the solar thermal STES based system. 
This financial analysis is based on an integrated system, with the solar array sized for use with an STES. Thus it is difficult to analyse the financial performance of each separate element in isolation. For example, the payback period for the DHW system is very high, as, while the DHW tank is appropriately sized to meet the DHW requirements, the solar array is too large to satisfy the DHW demand alone. Also while the system does meet a significant portion of the DHW and space heating demands directly (i.e. without use of the STES), the STES fulfils the dual requirement of providing long-term stored heat for winter use and also avoiding system stagnation during the summer months.

As has previously been stated the rate for electricity excludes any charge to cover the higher costs of the indigenous fuel peat and renewable energy in Ireland as this cost is currently based on an annual charge rather than a charge per unit of electricity. This may change in the future, as has been seen in Germany, where the cost of the renewable energy levy has increased from 3.6 cents to 5.27 cents per kilowatt-hour [35]. Further, the effects of electricity inflation have been modelled here using a $7.3 \%$ annual inflation rate. Recent price increases in the Republic of Ireland, the UK and Germany indicate that this may be conservative

All of the above variables are subject to change with a corresponding impact on the financial viability of the specific installation considered. It is noted that while a discount rate of $3 \%$ was used, this has been influenced by the low level of building activity pertaining at the time of writing and the consequent strategy of generating returns marginally above the rate of inflation. Further analysis is planned which will consider the impact of other fuel types and financial hypotheses, and will be the subject of a future paper.

This research along with the engineering analysis of a STES attached to a low energy dwelling [23], suggest a route to Near Zero Energy for dwellings in climates similar to Ireland. Cost engineering needs to be applied to the STES to reduce the financial burden imposed by installation and refurbishment. Furthermore, attention should be paid to reducing the parts and systems that will need to be fully replaced as is currently the norm. Increasing the service life of key components would have a significant impact on the financial analysis.

It should be noted, as the work carried out by Persson and Westermank [31] has demonstrated, despite the disadvantages with building smaller STES, from a behavioural economics perspective, STES when combined with low energy dwellings can constitute smaller market barriers, thereby leading to a more attractive proposition to potential consumers. Further work needs to be done in this area and its application to low-energy buildings and seasonal thermal energy storage.

Finally, at a policy level, consideration should be given to how best to facilitate citizens in benefitting from the long term benefits of STES in meeting the EU Near Zero Energy Targets. In the same way that Feed in Tariffs have facilitated the PV industry in a number of European countries, governments should consider incentivising STES. This could perhaps be achieved through the use of the Renewable Heat Incentives initiative seen in the UK. The analysis should be carried out for the UK market, considering the recent introduction of the renewable heat incentive, where the economic argument for the solar DHW and space heating system may be significantly enhanced by the inclusion of the STES.

\section{Acknowledgements}

This work was undertaken as part of the Irish Governments Charles Parsons Initiative, and the COST Network TU0802 Next Generation Cost Effective Phase Change Materials for Increased Energy Efficiency in Renewable Energy Systems and Buildings (www.tu0802.eu).

\section{References}

[1] EU, 2010-last update, Energy Performance of Buildings Directive (recast). Available:

http://www.eceee.org/buildings/EPBD_Recast/EPBD_recast_19May2010.pdf/at_download/file [June/2013, 2010/31/EU].

[2] FEIST, W. and ADAMSON, B., 1989. Design of Low Energy Houses in the Federal Republic of Germany. Report BKL 1989:3(E). Institute of Technology, Lund University: .

[3] FEIST, W., 1993. Passivhäuser in Mitteleuropa (Passive Houses in Central Europe) , University of Kassel. 
[4] SCHNIEDERS, J. and HERMELINK, A., 2006. CEPHEUS results: measurements and occupants' satisfaction provide evidence for Passive Houses being an option for sustainable building. Energy Policy, 34(2), pp. 151-171.

[5] BADESCU, V., LAASER, N., CRUTESCU, R., CRUTESCU, M., DOBROVICESCU, A. and TSATSARONIS, G., 2011. Modeling, validation and time-dependent simulation of the first large passive building in Romania. Renewable Energy, 36(1), pp. 142-157.

[6] GUERRA-SANTIN, O., TWEED, C., JENKINS, H. and JIANG, S., Monitoring the performance of low energy dwellings: two UK case studies. Energy and Buildings, Volume 64(September 2013), pp. Pages 32-40.

[7] RIDLEY, I., CLARKE, A., BERE, J., ALTAMIRANO, H., LEWIS, S., DURDEV, M. and FARR, A., 2013. The monitored performance of the first new London dwelling certified to the Passive House standard. Energy and Buildings, 63(0), pp. 67-78.

[8] Passive House Institute, 28 November 2011-last update, What is a Passive House? Available: http://www.passipedia.org/passipedia_en/basics/what_is_a_passive_house [May 22, 2013].

[9] CLARKE, A. and GRANT, N., 2010. The importance of hot water system design in the Passivhaus, 14th International Passive House Conference 2010, pp. 133--138.

[10] YOHANIS, Y.G. and NORTON, B., 2000. A comparison of the analysis of the useful net solar gain for space heating, zone-by-zone and for a whole-building. Renewable Energy, 19(3), pp. 435-442.

[11] MACGREGOR, K., 2006. A Comparison of EU Capital Cities for Suitability for Solar Space Heating, EuroSun, 27-30 June 20062006.

[12] HADRON, J., ed, 2005. Thermal Energy Storage for Solar and Low-Energy Buildings. State-of-theart. International Energy Agency Solar Heating and Cooling Programme.

[13] SCHMIDT, T., MANGOLD, D. and MULLER-STEINHAGEN, H., 2003. Seasonal Thermal Energy Storage in Germany, ISES Solar World Congress 2003, pp. available from http://www.tzs.unistuttgart.de/abteilungen/rationelleEnergie/pdfdateien/03-06.pdf.

[14] SCHMIDT, T. and MULLER-STEINHAGEN, H., 2004. The Central Solar Heating Plant with Aquifer Thermal Energy Store in Rostock - Results after four years of operation, EuroSun 2004 - The 5th ISES Europe Solar Conference, 20-23 June 2004, 2004.

[15] DINCER, I. and ROSEN, M., 2002. Thernal Energy Storage. Systems and Applications. Chichester, England: Wiley.

[16] ANON, 2013. Irish Housing Statistics. Dept of Environment, Community and Local Government.

[17] AHERN, C., GRIFFITHS, P. and O'FLAHERTY, M., 2013. State of the Irish housing stockModelling the heat losses of Ireland's existing detached rural housing stock \& estimating the benefit of thermal retrofit measures on this stock. Energy Policy, 55, pp. 139-151.

[18] BADESCU, V. and STAICOVICE, M.D., 2006. Renewable energy for passive house heating. Model of the active solar heating system. Energy and Buildings, 38, pp. 129--141.

[19] LECKNER, M. and ZMEUREANU, R., 2011. Life cycle cost and energy analysis of a Net Zero Energy House with solar combisystem. Applied Energy, 88(1), pp. 232-241.

[20] HUGO, A., ZMEUREANU, R. and RIVARD, H., 2010. Solar combisystem with seasonal thermal storage. Journal of Building Performance Simulation, 3(4), pp. 255-268.

[21] Obtained from http://www.degreedays.net/ for location ICOGALWA3: Moycullen, Galway, CO. GALWAY, IRELAND (9.18W,53.33N) (7mi/11km). Accessed 12 Aug 2015. 
[22] COLCLOUGH, S., GRIFFITHS, P. and SMYTH, M., 2010. Solar Energy Storage - Critical Success Factors for Passive Houses in Ireland, World Renewable Energy Congress XI 2010.

[23] COLCLOUGH, S.M., 2011. Thermal energy storage applied to the Passivhaus standard in the Irish climate, University of Ulster.

[24] COLCLOUGH, S.M., GRIFFITHS, P.W. and HEWITT, N.J., 2012. A Year in the Life of a Passive House with Solar Energy Store, International Conference on Sustainable Energy Storage, Belfast, Northern Ireland 21 to 23 February 20112012.

[25] COLCLOUGH, S.M., GRIFFITHS, P.W. and HEWITT, N.J., 2012 . Meeting Residual Heat Loads in a Passivhaus Using Solar Energy and a Seasonal Store, CIBSE ASHRAE Technical Symposium, Imperial College, London 18th 19th April 20122012.

[26] CLARKE, J., COLCLOUGH, S., GRIFFITHS, P. and MCLESKEY, J.T., 2013. A passive house with seasonal solar energy store: in situ data and numerical modelling. International Journal of Ambient Energy, pp. $1-14$.

[27] COLCLOUGH, S. and MCGRATH, T., 2015. Net energy analysis of a solar combi system with Seasonal Thermal Energy Store. Applied Energy, 147, pp. 611-616.

[28] IEA, 2003. Solar Combisystem - European Overview of installed Systems 2001-2003. Altener Contract Number: 4.1030/C/00-002/2000.

[29] KALOGIROU, S.A., 2009. Chapter twelve - Solar Economic Analysis. In: S.A. KALOGIROU, ed, Solar Energy Engineering. Boston: Academic Press, pp. 665-701.

[30] DECC, 2013-last update, Renewable Heat Incentive. Available: https://www.gov.uk/government/policies/increasing-the-use-of-low-carbon-technologies/supportingpages/renewable-heat-incentive-rhi [May 29, 2013].

[31] Persson, J. \& Westermark, M. 2013, "Low-energy buildings and seasonal thermal energy storages from a behavioral economics perspective", Applied Energy, vol. 112, no. 0, pp. 975-980.

[32] United Nations Solar Thermal Energy Technology Fact Sheet. Available: http://www.unep.org/training/programmes/Instructor\%20Version/Part_2/Activities/Innovations_and_Technolog y/Energy/Strategies/Solar_Thermal.pdf [November, 4, 2013].

[33] EUROSTAT, Annual Average Rates of Inflation. Available: http://ec.europa.eu/eurostat/statisticsexplained/index.php/Inflation in the euro_area 07/2015].

[34] ESB, , Electricity Supply Board - Electricity Price Plans. Available: https://www.electricireland.ie/switchchange/pricePlanElec.htm [February, 2013].

[35] DEUTSCHE WELLE, German Green Electricity Levy almost doubles. Available: http://www.dw.de/german-green-electricity-levy-almost-doubles/a-16306338 [June, 2013]. 